\title{
Evaluation of the Genotoxicity in Fish Erythrocytes to Diagnose the Water Quality of Two Amazonian Estuaries Using the Micronucleus Test and Comet Assay
}

CLAUDIA ANTONIA CAMPOS RODRIGUES DE OLIVEIRA ( $\nabla$ claudia.engpesca@yahoo.com.br) Universidade Federal do Para https://orcid.org/0000-0002-1421-2085

\section{Paulo Sergio dos Santos Souto}

Universidade Federal Rural da Amazônia: Universidade Federal Rural da Amazonia

Dulcideia da Conceição Palheta

Universidade Federal Rural da Amazônia: Universidade Federal Rural da Amazonia

Marcelo de Oliveira Bahia

Universidade Federal do Pará: Universidade Federal do Para

Lorena Araújo da Cunha

Universidade Federal do Pará: Universidade Federal do Para

Maria de Lourdes Souza Santos

Universidade Federal Rural da Amazônia: Universidade Federal Rural da Amazonia

Tatiane do Nascimento Medeiros Rodrigues

Universidade Federal do Pará: Universidade Federal do Para

\section{Bianca Bentes}

Universidade Federal do Pará: Universidade Federal do Para

\section{Research Article}

Keywords: biomarkers, environmental monitoring, cells, xenobiotic agents, biomonitoring, environmental toxicology

Posted Date: October 22nd, 2021

DOI: https://doi.org/10.21203/rs.3.rs-849055/v2

License: (1) This work is licensed under a Creative Commons Attribution 4.0 International License.

Read Full License 


\section{Abstract}

Genotoxicity studies in coastal ecosystems have been a priority in Environmental Risk Assessment (ERA). This research aimed to study the genotoxicity by the micronucleus test and comet assay in two Brazilian Amazon estuaries (anthropized and control) using Plagioscion squamosissimus as a bioindicator. Blood samples were collected from 54 specimens. No significant genotoxic effects were detected in the cells analyzed, although the highest occurrence was observed in anthropized site. The percentage of genomic damage differed between the sites studied, being always higher in anthropizes site as well. Of the nucleoids analyzed in this site, on average $28 \pm 14.42 \%$ of the cells were classified in the highest damage class (4). The fish analyzed in the present study are direct influence of xenobiont agents capable of producing damage to the genetic material of aquatic organisms in both sites and, consequently, may bring consequences still little reported in studies of morphophysiological alterations in humans.

\section{Introduction}

The hematological analysis of fish exposed to contaminants has been used increasingly for the monitoring of environmental quality, considering that these organisms respond to toxic compounds in a manner similar manner to other higher vertebrates, and may thus be used as bioindicators for the evaluation of chemical substances that are potentially teratogenic or carcinogenic in humans (Rivero, 2007; Ranzani-Paiva et al., 2013; Oliveira \& Valdes, 2019). A number of different analytical tools have been developed for the detection of these alterations, including the comet assay, also known as Single Cell Gel Electrophoresis (SCGE), which has been widely used to test for the effects of the genotoxic agents found in industrial, domestic, and agricultural waste, which may damage the DNA or induce repairs to this material in a given environment, as well as being employed in cancer research (Hartmann et al., 2003; White \& Rasmussen, 1998). This type of assay was proposed by Ostling and Johanson (1984), and can be used in a range of different applications, including toxicological genetics, ecotoxicology, and studies of DNA repair and apoptosis. The technique was modified and perfected by Singh et al. (1988), through the introduction of alkaline conditions, and the development of single cell electrophoresis, which has been adopted by the majority of the laboratories that use this approach in tests of genetic toxicology (Moller, 2005; Rivero, 2007).

The micronucleus test ( $\mathrm{MN})$, which is used as an experimental model for the detection of the genotoxic effects provoked by a range of physical and chemical agents, is a second widely-used method in studies of environmental genotoxicity (Ranzani-Paiva et al., 2013; Hussain et al., 2018). These procedures evaluate the effects of polluants on the biota of contaminated aquatic environments, to which humans may also be exposed (Matsumoto, 2006; Martins et al., 2010; Ranzani-Paiva et al., 2013). The micronucleus test was developed by Schmid (1975), who initially focused on mammalian bone marrow cells, and has been used extensively to test the genotoxicity of chemical compounds in invertebrates, fish, and amphibians, with excellent results for the monitoring of contaminated areas. The frequency of micronuclei observed at any given moment can be considered to reflect the complex interaction between the genotoxic activity and the physiological mechanism of the test 
organism. In contrast with mammals, micronuclei are found in the peripheral blood of fish, which avoid the need to extract the bone marrow (Mersch et al., 1996; Campana et al., 2003).

Considering the ecological and economic importance of the Amazonian estuaries that were the focus of the present study, the identification of the possible impacts caused by local bauxite smelting operations would provide important insights for the implementation of measures designed to minimize the deleterious effects of these impacts on the local biota and, ultimately, the human populations in the area. Given this, the present study investigated environmental toxicity in the Murucupi River, an environment impacted by an industrial complex, and Furo da Laura, a control area, using the South American silver croaker, Plagioscion squamosissimus (Heckel, 1840) as a bioindicator of environmental quality. This species is an important fishery resource in both study areas, where it is consumed by the local population, and is also exported as a fishery product (Viana, 2011; Furtado-Júnior et al., 2015).

\section{Materials And Methods}

The collection of the fish specimens analyzed in the present study was authorized by the Ethics Committee for the Use of Animals in Research (CEUA) of the Federal University of Pará in Belém, Brazil, through license number 727721082 (Appendix 1). Specimen collection was also authorized by the federal Biodiversity Information and Authorization System (SISBIO), through license number 15080-9 (Appendix 2).

\subsection{Study areas}

The present study was based on the analysis of samples of the peripheral blood of $P$. squamosissimus collected in two estuarine environments, the Murucupi River, an environment that suffers anthropogenic impacts, and Furo da Laura, which was used as the control area. The samples were collected during the dry season month of August, 2020, and the rainy season month of March, 2021. These areas were selected due to their proximity to the Pará state capital, Belém, the city in which the laboratories for the toxicological analyses are located.

The Murucupi River (Fig.1), which is the principal watercourse of the Murucupi hydrographic basin, is located in the municipality of Barcarena, in northeastern Pará state, in northern Brazil. This municipality is part of the metropolitan region of Belém, the Pará state capital, which is located within the Lower Tocantins microregion. This river was selected for the present study due to the high level of contamination of the water, derived from the effluents discharged by local residences and industrial installations (Silva, 2013; Hazeu, 2015; Piratoba et al, 2017). The river is approximately 8 km long, between its source in the area of environmental preservation near a tailing pond for the red mud produced by the Hydro/Alunorte bauxite smelting plant, and the Furo do Arrozal, a tributary of the Pará River, while passing through the principal urban centers of the municipality of Barcarena (Oliveira, 2013; Costa, 2015; Santos, 2018). The region has a rainy equatorial climate, with mean annual precipitation of $2,587.7 \mathrm{~mm}$, and rainfall of more than $60 \mathrm{~mm}$ in most months (Cunha, 2018). 
The Furo da Laura estuary (Fig.2) is the principal hydrographic feature of the municipality de Vigia, in north-eastern Pará, in the state's Salgado microregion. This ample estuary has a heavy daily traffic of both artisanal and industrial fishing vessels (Lima et al., 2015). The margins of the estuary are dominated by Holocenic salt marshes and mangroves (Lima et al., 2015), with the vegetation cover being formed primarily by a mixture of mangrove forest and typical terra firme vegetation (Cardoso, 2009). The local climate is typical of the equatorial Amazon, being super-humid with relatively high temperatures, i.e., $26-39^{\circ} \mathrm{C}$ (Mesquita, 2020), with a marked division into rainy and dry (or less rainy) seasons, with monsoon-type rains during the six first months of the year (January through June), that is, the rainy season, and much drier conditions during the second half of the year (July through December), which is defined as the dry season (Silva et al., 2011).

\subsection{Collection and preparation of the samples}

The specimens were collected with the assistance of local fishers, who captured the animals in fish weirs of varying sizes (young and adults, considering the tamanho de primeira maturação sexual estimado por Lima et al., 2019), which contributed to the minimization of any selective effects in terms of specimen size, with stress being reduced using the approach of Ishikawa et al. (2010). The fish were placed immediately in a bucket containing water and $2 \%$ benzocaine $(190 \mathrm{mg} / \mathrm{L})$ for approximately 3 minutes prior to biometry and the collection of blood samples. The standard sample was originally expected to be at least 20 specimens per season per site. Blood samples were collected from blood vessels in the caudal portion of each fish using $3 \mathrm{ml}$ syringes containing the anticoagulant EDTA (ethylenediaminetetraacetic acid), following the method proposed by Ranzani-Paiva et al. (2013) and Ishikawa et al. (2010). Once the samples were collected, each individual was weighed (in grams) with a semi-analytic balance, and its total length $(T L$, in $\mathrm{cm}$ ) was measured using an ichthyometer. All individuals were then released back into the water. The blood samples were stored in Eppendorf type micro-centrifugation tubes, which were kept on ice in a cooler at a temperature of $5-7^{\circ} \mathrm{C}$ (Ishikawa et al., 2010) for transportation to the laboratory. The comet assays were based on the procedure of Singh et al. (1988), with minor modifications (Hartmann; Speit, 1997).

The DNA damage was visualized at a magnification of 1000x under an epifluorescence microscope equipped with a 515-560 nm excitation filter and $590 \mathrm{~nm}$ barrier filte. For the comet assays, being allocated to one of the five damage classes defined by Collins et al. (2001). Using a cell counter, 100 nucleoids were counted per animal, that is, 50 on each slide, using the visual classification approach based on the migration of the DNA fragments, with the damage being assigned to one of five classes (Wachtel, 2017): 0 (no apparent damage), 1 (some damage), 2 (moderate damage), 3 (extensive damage), and 4 (maximum damage, apoptosis). These numerical values were considered to be the ranks of the damage classes (0-4) for the statistical analyses. The DNA damage index (DI) was calculated according to the following formula: DI (au): [(N1 $* 1+2 * 2+3 * 3+4 * 4)] / 100$ (total number of analyzed cells), where DI is the DNA damage index, au is the arbitrary unit, and N1-N4 are cells in classes $1,2,3$, and 4. The micronucleus tests were conducted following Al-Sabti \& Metcalfe (1995), using blood 
on clean, labeled slides. The frequency of micronuclei was determined based on the method proposed by Carrasco et al. (1990) and Oliveira et al. (2020). Once stained, the slides were visualized under an immersion optical microscope at a magnification of $1000 x$. A total of 2,000 cells were analyzed per individual, to determine the number of micronuclei and morphonuclear alterations (MNA) present in each cell, using a Zeiss Primo Star optical microscope at a magnification of $1000 x$, with a manual blood cell counter. The data were recorded in Microsoft Excel $®$ spreadsheets.

In addition to the presence of micronuclei, the nuclear abnormalities present in the cells were described, counted, and classified following Carrasco et al. (1990) as: (1) blebbed (nucleus with a minor evagination of the nuclear membrane with euchromatin or heterochromatin); (2) lobed (nucleus with larger and more ample evagination than the blebbed cells); (3) vacuolated (nucleus containing vacuoles) or (4) notched (nucleus well defined morphologically). The data on the quality of the water of the Murucupi River were obtained from the HIDROWEB site of the Brazilian National Water Agency (ANA), as well as monitoring by the Chemical Environmental Laboratory (LQA) of the Federal Rural University of Amazonia (UFRA) in Belém.

\subsection{Statistical analyses}

The number of micronuclei and morphonuclear alterations were analyzed per specimen, considering the site (natural or anthropogenic), and the relative size of the specimens, as well as all possible combinations of these variables. Prior to the analyses, the data were tested for normality and the homoscedasticity of variances, to ensure the application of one-way and factorial Analyses of Variance (ANOVA), considering an error of 5\%. The analyses were all run in the Statistica 10.0 software.

Finally, a Redundancy Analysis (RDA) of all the effects and factors analyzed in the study was run in CANOCO 4.5 (Software for Canonical Community Ordination), with the significance of the contribution of the independent variables (study areas and specimen size) to the variability in the data being assessed by 9999 permutations (Monte Carlo Method). This analysis included only the significant $(p<0.05)$ variables identified in the analysis. The dependent variables (the percentage of micronuclei and the categories of DNA damage) were allocated to separate presence/absence matrices, in which each line represents an individual, with each matrix being related to a second ('treatment') matrix, to which the independent variables were added one by one.

\section{Results}

A total of 54 specimens were collected during the present study, in the two estuaries. The fish collected in Vigia were significantly larger $(T L)$ on average than those from Barcarena $(F=17.69 ; p<0.01)$, although the specimens from Barcarena were heavier than those from Vigia (Table 1), but the difference was not significant $(F=0.085 ; p>0.05)$. 
No significant variation was found in the $\mathrm{pH}$, although the dissolved oxygen concentrations were lower in the Murucupi River than Furo da Laura. The highest nitrate concentrations were recorded in Barcarena in both seasons (Table 2).

\subsection{Comet assays}

The DNA Damage Index varied significantly between the study sites $(F=64.96, p<0.01)$, and was higher in Barcarena than in Vigia (Fig. 3). Table 3 shows the distribution of the different nucleoid classes observed in the samples from the two study sites. On average, $28.25 \pm 14.4 \%$ of the nucleoids analyzed in the samples from Barcarena were assigned to the highest damage class (4), whereas only $1.8 \%$ of the cells in the samples from Vigia were assigned to this class (Table 3 ).

\subsection{Micronuclei and morphonuclear alterations}

A total of 107,990 erythrocytes were analyzed in the present study. Overall, the largest number of abnormal cells was observed in the specimens from Barcarena (Table 5). All the nuclei observed with abnormalities were of the evagination type.

\subsection{Uni- and multi-variate analyses}

The fish collected in the municipality of Vigia were larger $(T L)$, on average, than those collected in Barcarena, although the latter were heavier. Significant differences were recorded between the Vigia and Barcarena samples in the mean number of cells in damage classes $0,2,3$, and 4 , with the largest numbers in all classes except 0 being recorded at Barcarena, peaking in class 4 (in absolute and relative terms), with a mean of $28.25 \pm 14.43$ in comparison with $1.8 \pm 2.20$ at Vigia (Table 5; Fig. 3). The difference between estuaries in class 1 was not significant. The morphonuclear alterations recorded at Vigia were not significantly different from those recorded at Barcarena, although the presence of micronuclei at Barcarena was much greater than that recorded at Vigia (Table 5; Fig. 3).

In the Redundancy Analysis, the highest nitrate concentrations were recorded in quadrants 1 and 2 (Fig. 4), which were associated with the impacted area (Barcarena), while the highest $\mathrm{pH}$ and dissolved oxygen concentrations were associated with Furo da Laura, where the lowest levels of genomic damage and morphonuclear alterations were recorded, and the lowest number of erythrocytes with micronuclei.

Overall, then, the cellular effects analyzed in the present study are associated with the quality of the water in the two study estuaries, given that the factors tested accounted for $76.31 \%$ of the variability in the data (Table 6).

\section{Discussion}


Fish have been used as environmental biondicators in a number of genotoxic studies (Grisólia and Cordeiro, 2000; Souto, 2004; Arias et al., 2007; Costa et al., 2008; Delunardo et al., 2013; Carrola et al., 2014; Lima et al., 2015; Rocha et al., 2016; Bueno et al., 2017; Hussain et al., 2018; AnvariFar et al., 2018; Delunardo et al., 2020; Santana et al., 2020). These vertebrates are appropriate models for this type of research due to their capacity for the metabolization and accumulation of pollutants that also pose a risk to humans (Ranzane-Paiva, 2013; Ventura, 2015; Lima et al., 2015). Plagioscion squamosissimus is an important fishery resource in the Amazon region, providing subsistence and a source of income for many local populations (Chao et al., 2015; Barbosa et al., 2021), although this species is also an important animal model for the biomonitoring of aquatic environments (Viana et al., 2013; Rocha et al., 2016), given its sensitivity to toxic substances, as well as its relative abundance in most areas (Jonsson and Castro, 2005; Santos et al., 2020). In the present study, significantly higher levels of damage were recorded in the $P$. squamosissimus treatment (contaminated) group in comparison with the control in both the comet assays and the micronucleus test.

In the present study, the fish collected in the municipality of Barcarena were shorter (TL), on average, than those from Vigia, but heavier, with higher frequencies of micronuclei, nuclear alterations, and indices of comet damage in comparison with Vigia, which point to the influence of the differences in the quality of the water in the two estuaries. In particular, while the maximum damage class (4) was the most frequent in the Barcarena samples, with $28 \%$ of the nucleoids analyzed, it was the least frequent class (1.8\%) in the Vigia samples, where a majority of the nucleoids (59\%) were undamaged (class 0 ). The results of the micronucleus test were similar to the findings of Santos et al. (2015), who analyzed the weight-length ratio and the frequency of micronuclei in the tambaqui, Colossoma macropomum, exposed to agricultural toxins and herbicides in northern Brazil. As in the present study, these fish had gained relatively more weight than length, and the correlation between the weight-length ratio and the micronucleus test may be a useful parameter for the biomonitoring of contaminated environments (Santos et al., 2015), as well as providing important insights into the physiological condition of fish exposed to pollution, given that animals from more impacted environments tend to have a lower condition factor $(K)$ than those from unpolluted areas (Oliveira-Ribeiro et al., 2013).

As in the present study, descriptive indicators of size classes have been used in a number of studies to evaluate the seasonal and spatial variation in fish communities, which may be related to shifts in the behavior of the species and their physiological response to pollution (Arias et al., 2007; Costa et al., 2008; Copatti \& Copatti, 2011. Santos et al., 2015). In Senegal, for example, a reduction of the maximum length of the fish of a community was observed after 20 years of anthropogenic impact (Ecoutin et al., 2010). However, the fish collected from the Murucupi River in the present study were similar in size to those collected from this same river by Oliveira et al. (2019).

This study showed that the physical and chemical parameters of the water are complemented by the toxicity tests, given that these tests evaluate the potential effects of the substances found in the water on the local biological system. In the present study, the dissolved oxygen concentrations recorded in the Murucupi River were lower than those found in the control area, but higher than those recorded by Pereira 
et al. (2007), that is, $2.6 \mathrm{mg} / \mathrm{L}$, which is well below the concentration recommended in resolution 357 of the Brazilian National Environment Council, CONAMA (DO > $5.0 \mathrm{mg} / \mathrm{L}$ ). These authors associated the low dissolved oxygen concentration recorded in the Murucupi River with a significant increase, above natural levels, in the organic matter in the water, which was derived from the effluents discharged into the river. The relatively acid $\mathrm{pH}$ recorded in both study areas in both seasons is typical of Amazonian watercourses, which tend to be relatively rich in kaolinite and humic acid derived from the decomposition of plant material (Pereira et al., 2007; Medeiros et al., 2017).

The endogenous occurrence of micronuclei is well documented, although it rarely exceeds one micronucleus per thousand cells, i.e., $0.1 \%$ (Thomé et al., 2016). There is no strict consensus on the number of cells that need to be analyzed per animal to provide a reliable estimate of the frequency of micronuclei, with published studies being based on samples of between 1,000 and 10,000 cells. Ghisi et al. (2010) investigated the optimum sample size with the aim of standardizing procedures, and compared counts of $1,000,2,000,3,000$, and 4,000 cells, eventually reaching the conclusion that a sample of only 1,000 cells provided satisfactory results. In the present study, the counts of 2,000 erythrocytes per animal proved to be more than adequate for the identification of micronucleated cells and nuclear alterations in the erythrocytes of $P$. squamosissimus from the two study estuaries. The numbers of micronuclei and morphological nuclear alterations found in both Barcarena and Vigia were similar to the findings of Rocha et al. (2016), who also used $P$. squamosissimus as a bioindicator in the Marajó Archipelago of northern Brazil, although the values were much higher than those recorded in the Nile tilapia, Oreochromis niloticus (Cichlidae), by Bueno et al. (2017) from a reservoir in southeastern Brazil during both the dry and rainy seasons. The high genotoxic concentrations observed in the water from the impacted area during the rainy season may be linked to the more intense rains, given that Silva et al. (2014) found that more intense rainfall provokes a greater lixiviation of the chemical substances into the river from the surrounding soil.

The comet assay is not used to detect mutations per se, but rather, genomic lesions that can, in fact, be corrected, and can thus also be used to study DNA repair mechanisms, providing important insights into the kinetics and the type of lesion that has undergone repair, although it cannot confirm the adequacy of the repair process itself (Albertini et al., 2000). The frequencies of the nucleoid classes analyzed in Barcarena were similar to those recorded by Rocha (2009) in the peripheral blood of $C$. macropomum and the saddle cichlid, Aequidens tetramerus (Cichlidae), exposed to different concentrations of methylmercury. This study showed that the damage levels detected by the comet assay were greater than those observed in the micronucleus test, a pattern similar to the results of the present study, which can be considered to be the normal pattern, given that the comet assay evaluates primary DNA damage, which is rarely passed down to future generations of cells.

The high percentages of micronuclei, nuclear alterations, and comet damage observed in the $P$. squamosissimus specimens from Barcarena may be related, in part, to the piscivorous feeding habits of this species. Porto et al. (2005) evaluated the genotoxic effects of mercury pollution in three fish species of the order Characiformes with distinct feeding adaptations, using the micronucleus test, 
and found that the mean frequency of micronuclei in the piscivorous species was approximately five times higher than those recorded in the detritivorous and omnivorous species. Hussain et al. (2018) also used the micronucleus test, nuclear alterations, and comet assay to investigate the effects of exposure to industrial and domestic effluents in the rohu, Labeo rohita (Cyprinidae), in the Chenab River in Faisalabad, Pakistan. This study recorded acute levels of toxicity and high contamination rates, which contributed to an increase in the mortality of the fish, which indicated that the water of the river should not be used even for irrigation.

The smelting plant in Barcarena belongs to one of the world's largest corporations in the aluminum sector. Over the past 20 years, a number of environmental accidents related to the processing of bauxite have been recorded in the municipality, in particular the 2018 incident, when toxic red mud leaked from one of the tailing ponds, which was considered to have been one of the most significant environmental disasters in the history of the Amazon region (Steinbrenner et al., 2020). Following this incident, the company received an official warning, and was required to implement a number of mitigatory measures (Lemos and Pimentel, 2021).

Given the potential impact of the smelting plant, a number of studies have investigated the damage to the Murucupi River, in particular the concentrations of heavy metals present in the water and the local soils (Pereira et al., 2007; IEC, 2009, 2018; Lima et al., 2015; Medeiros et al., 2016 and 2017; AlmeidaJunior et al., 2019), as well as the water-borne diseases transmitted to the local population (Marinho, 2016). Pereira et al. (2007) recorded aluminum concentrations 13.2 times higher than the recommended level in the water of the Murucupi River. In high concentrations, aluminum may provoke neurological disorders in human beings, such as Alzheimer's and Parkinson's diseases (SILVA JÚNIOR, 2013). In fish, the aluminum dissolved in acidic water, which comes into contact with the gills, provokes an increase in the $\mathrm{pH}$ and the formation of insoluble $\mathrm{Al}_{2}(\mathrm{OH})_{3}$, which damages the DNA (Muniz and Oliveira-Filho, 2006; Sultana et al., 2020) and eventually suffocates the animal. This has raised a number of concerns in the population of Barcarena in terms of the quality of the fish available for human consumption in the region. Barros et al. (2010) and Foran (1990) concluded that the health risks of the consumption of contaminated fish are 20-40 times higher than those associated with the ingestion of contaminated water, given that aquatic organisms are capable of concentrating trace elements to up to 105 times the concentrations observed in the environment. Marinho et al. (2016) evaluated the profile of the morbidity of the residents of the municipality of Barcarena and the surrounding area, and concluded that a number of different infirmities caused by parasites, as well as infectious and respiratory diseases, may be maximized by the poor quality of the water and other natural resources used as a source of food by this population. This highlights the need for a more detailed quantitative and qualitative investigation of possible environmental contamination in the region.

The analyses employed in the present study permitted the application of a holistic approach to the investigation of the environmental variables that affect the biological parameters of $P$. squamosissum, providing, with multivariate analyses, a powerful tool for the interpretation of complex data on water quality. Shrestha and Kazama, (2007) evaluated the efficiency of statistical models for the analysis of 
water quality data, based on the standard parameters most frequently employed, and concluded that the data on river discharge, temperature, the biochemical demand for oxygen, $\mathrm{pH}$, electrical conductivity, nitrate, and ammoniated nitrogen are the parameters that best correlate with the quality of the water of aquatic environments, and should be employed in this type of analysis. In the present study, the temperature, $\mathrm{pH}$, and dissolved oxygen were employed, with clear results in terms of the deleterious effects on the watercourses and one of the principal local fishery resources, i.e., P. squamosissimus.

Considering the ecological and economic importance of the Amazonian es-tuaries that were the focus of the present study, the identification of the possible impacts caused by local bauxite smelting operations would provide important insights for the implementation of measures designed to minimize the deleterious effects of these impacts on the local biota and, ultimately, the human populations in the area. Adequate mitigatory measures should guarantee the productivity of these environments for future generations, especially considering the importance of their fishery resources as a source of income and subsistence for the traditional local populations. This is the first study of its type in this region, and it provides important insights into the physiological response of the species to the environmental alterations evaluated in the analyses. Direct and immediate action is necessary from the public authorities to ensure the highest level of care with the treatment and storage of the residues in the tailing ponds to avoid potentially major impacts on the local rivers. The present study also provides the first detailed data on genotoxicity in the fish populations of the study area.

\section{Declarations}

Ethics approval and consent to participate (The collection of the fish specimens analyzed in the present study was authorized by the Ethics Committee for the Use of Animals in Research (CEUA) of the Federal University of Pará in Belém, Brazil, through license number 727721082 (Appendix 1). Specimen collection was also authorized by the federal Biodiversity Information and Authorization System (SISBIO), through license number 15080-9)

Consent for publication (All authors are aware of the publication of data in this article)

Availability of data and materials (Not applicable)

Competing interests (Not applicable)

Funding (This study was financed in part by the Coordenação de Aperfeiçoamento de Pessoal de Nível Superior-Brasil (CAPES) - Finance Code 001).

Authors' contributions (Not applicable)

Acknowledgements (Not applicable)

Authors' information (Not applicable) 
Author contribution statement

All authors contributed to the study conception and design.

CACRO "collected and captured the animals in the field and analyzed the data of the comet and micronucleus assay in the laboratory"

PSSS "performed the collection in the field"

DCP "analyzed the micronucleus in the laboratory"

MOB "interpreted the data from the comet assay"

LAC "performed the comet test procedures"

MLSS "performed the water collections and analysis"

TNMR "assistance in writing and reviewing the manuscript"

BB "assistance in writing and reviewing the manuscript"

\section{References}

1. Al-Sabti K, Metcalfe CD (1995) Fish micronuclei for assessing genotoxicity in water. Mutation esearch/Genetic Toxicology 343(2-3):121-135. DOl:10.1016 / 0165-1218 (95) 90078-0

2. Anvari Far H, Amirkolaie AK, Jalali AM, Miandare HK, Sayed A E D H, Üçüncü SI, Ouraji H, Ceci M, Romano N (2018) Environmental pollution and toxic substances: Cellular apoptosis as a key parameter in a sensible model like fish. Aquat Toxicol 204:144-159.

DOI:10.1016/j.aquatox.2018.09.010

3. Arias ARL, Buss DF, Albuquerque C, Inácio AF, Freire MM, Egler M (2007) Use of bioindicators for assessing and monitoring pesticides contamination in streams and rivers. Ciência, saúde coletiva. Rio de Janeiro Brasil 12(1):61-72. DOl:https://doi.org/10.1590/S1413-81232007000100011

4. Almeida-Junior CF, Silva LP, Santos MAB, Ribeiro RP (2019) Physical-chemical analysis of rural Murucupi water located in Barcarena-PA. Braz J of Develop Curitiba 5(10):21292-21301. DOI:10.34117/bjdv5n10-287

5. Barros BCV, Pinheiro SF, Palheta DC, Silva CS (2010) Cd, Cr and Al determination in fish tissue from gelado river/APA, Carajás-PA forest. Holos Environment 10(2):195-208.

DOI:10.14295/holos.v10i2.3668

6. Barbosa AJ, Sampaio I, Santos S (2021) Re-visiting the occurrence of mislabeling in frozen "pescada-branca" (Cynoscion leiarchus and Plagioscion squamosissimus-Sciaenidae) sold in Brazil using DNA barcoding and octaplex PCR assay. Food Res Int, (143).

DOI:https://doi.org/10.1016/j.foodres.2021.110308

Page $11 / 22$ 
7. Bueno APM, Vasconcelos MG, Francisco CM, Pavanin LA (2017) Teste de micronúcleos em peixes e parâmetros físico-químicos da água da represa Cocais, Minas Gerais. Acta Brasiliensis 1(3):32-36. DOl:https://doi.org/10.22571/Actabra13201755

8. Carrasco KR, Tilbury KL, Myers MS (1990) Assessment of the piscine micronucleus test as an in situ biological indicator of chemical contaminant effects. Can J Fish Aquat Sci 47(11):2123-2136. DOI:https://doi.org/10.1139/f90-237

9. Cardoso FF (2009) Dinâmica da comunidade microfitoplanctônica relacionada com os parâmetros físico-químicos do Estuário do Rio Guajará-Mirim. Vigia-PA).Dissertação,Universidade Federal do Pará

10. Carrola J, Santos N, Rocha MJ, Fontainhas-Fernandes A, Pardal MA, Monteiro RA, Rocha E (2014) Frequency of micronuclei and of other nuclear abnormalities in erythrocytes of the grey mullet from the Mondego, Douro and Ave estuaries - Portugal. Environ Sci Pollut Res, 21 (9), 6057-6068. DOI: 10.1007 / s11356-014-2537-0

11. Campana MA, Panzeri AM, Moreno VJ, Dulout FN (2003) Micronuclei induction in Rana catesbeiana tadpoles by the pyrethroid insecticide lambdacyhalothrin. Genetics Molecular Biology 26:99-103

12. Collins AR, Dusinská $M$, Horská $A$ (2001) Detection of alkylation damage in human lymphocyte DNA with the comet assay. Acta Biochim 48(3):611-614. DOl:https://doi.org/10.18388/abp.2001_3895

13. Chao NL, Frédou FL, Haimovici M, Peres MB, Polidoro B, Raseira M, Subirá R, Carpenterh K (2015) A popular and potentially sustainable fishery resource under pressure-extinction risk and conservation of Brazilian Sciaenidae (Teleostei: Perciformes). (4)117-126.

https://doi.org/10.1016/j.gecco.2015.06.002

14. Copatti CE, Copatti BR (2011) Seasonal variation and diversity of fishes of the Cambará River, Uruguay Basin. Biota Neotrop. 11(4): http://www.biotaneotropica.org.br/v11n4/en/abstract? inventory+bn02611042011. Acessado em: 24 de junho de 2021

15. Costa CR, Olivi P, Botta CMR, Espindola ELG (2008) Toxicity in aquatic environments: discussion and evaluation methods. Quim Nova 31(7):1820-1830. DOl:https://doi.org/10.1590/S010040422008000700038

16. Costa BNS (2015) Comunidade microzooplanctônica como indicadora de alterações ambientais em um polo industrial e portuário na região amazônica. Belém-PA. Dissertação, Universidade Federal do Pará

17. Cunha CMC (2018) Vulnerabilidade ambiental no município de Barcarena-PA: Análise da erosão nas praias do Caripí e da Vila do Conde, Ananindeua, Belém, Pará. Trabalho de conclusão de curso.Universidade Federal do Pará

18. Delunardo FAC, Silva BF, Paulino MG, Fernandes MN, Chippari-Gomes AR (2013) Danos genotóxicos e morfológicos em Hippocampus reidi exposto ao petróleo bruto. Ecotoxicol Environ Saf 87, 1-9. DOI:10.1016 / j.ecoenv.2012.09.029

19. Delunardo FAC, Paulino MG, Medeiros LCC, Fernandes MN, Scherer R, Chippari-Gomes AR (2020) Mudanças morfológicas e histopatológicas em guelras de cavalos-marinhos (Hippocampus reidi) 
após a exposição à fração de óleo diesel acomodada em água. Mar Pollut Bull 150, DOI:10.1016/ j.marpolbul.2019.110769

20. Ecoutin JM, Simier M, Albaret JJLAER, Tito de Morais $L$ (2010) Changes over a decade in fish assemblages exposed to both environmental and fishing constraints in the Sine Saloum estuary (Senegal). Estuarine, Coastal and Shelf Science. 87 (2) 284-292

21. Foran JA (1990) Toxic substances in surface Waters. Environ Sci Technol 24(15):604-608. DOl:https://doi.org/10.1021/es00075a002

22. Furtado-Júnior I, Tavares MCS, Matsunaga AMF (2015) Biodiversidade do Nécton do rio Pará nas proximidades de Itupanema-Barcarena- Amazônia Brasileira, Biota Amazônia, Macapá, 5 (3),7277.DOI: http://dx.doi.org/10.18561/2179-5746/biotaamazonia.v5n3p72-77

23. Goes IMC, Freitas JSA, Santos JMK, Maciel LAM, Portela A (2016) Avaliação da poluição do rio tapajós, no município de Santarém-PA, através do teste do micronúcleo, utilizando peixes como bioindicador. Revista de publicação acadêmica da pós-graduação do IESPES. 1-11. https://docplayer.com.br/50192441-Avaliacao-da-poluicao-do-rio-tapajos-no-municipio-de-santarempa-atraves-do-teste-do-micronucleo-utilizando-peixes-como-bioindicador.html. Acessado em 24 de Abril de 2021

24. Gomes LC, Chippari-Gomes Miranda A R T O, Pereira TM, Merçon J, Davel VC, Barbosa BV, Pereira A C H A, Frossard Ramos JPL (2019) Genotoxicity effects on Geophagus brasiliensis fish exposed to Doce River water after the environmental disaster in the city of Mariana, MG, Brazil. Brazilian Journal of Biology, 79 (4), 659-664.DOI: https://doi.org/10.1590/1519-6984.188086

25. Grisolia CK, Cordeiro CMT (2000) Variability in micronucleus induction with different mutagens applied to several species of fish. In:Genetics and Molecular Biology, $1^{\circ}$ Ed. pp 235-239

26. Hartmann A, Agurell E, Beevers C, Brendler-Schwaab S, Burlinson B, Clay P, Collins A, Smith A, Speit G, Thybaud V, Tice RR (2003) Recommendations for conducting the in vivo alkaline Comet assay. Mutagenesis. Mutagenesis, $1^{\circ} \mathrm{Ed}, \mathrm{pp}$ 45-51

27. Hazeu MT (2015) O não lugar do outro: Sistemas migratórios e transformações sociais em Barcarena. Tese, Universidade Federal do Pará

28. Hussain B, Sultana T, Sultana S, Masoud MS, Ahmed Z, Mahboob S (2018) Fish eco-genotoxicology: Comet and micronucleus assay in fish erythrocytes as in situ biomarker of freshwater pollution. Saudi Journal of Biological Sciences 25:393-398. DOl:https://doi.org/10.1016/j.sjbs.2017.11.048

29. Instituto Evandro Chagas (IEC) (2009) Relatório técnico SAMAM 001: caracterização dos impactos ambientais, danos ao ecossistema e riscos à saúde decorrentes do lançamento no rio Murucupi de efluentes do processo de beneficiamento de bauxita, Barcarena-Pará. Ananindeua, PA, Brasil. 32 p. http://iah.iec.pa.gov.br/iah/fulltext/ pc/relatorios/barcarena2009.pdf. Acessado em 30 de Maio de 2021

30. Instituto Evandro Chagas (IEC) (2018) Relatório técnico RT SAMAM 10.2 - 001: Avaliação preliminar dos impactos ambientais referente ao transbordo e lançamentos irregulares de efluentes de lama vermelha na cidade de Barcarena, estado do Pará. Ananindeua, PA, Brasil. 51 p. 
https://www.iec.gov.br/wp-content/uploads/2018/03/RELAT\%C3\%93RIO-T\%C3\%89CNICO-0032018-Final-Tabelas-Modificadas-SS-1.pdf. Acessado em 30 de Maio de 2021

31. Ishikawa MM, Pádua SB, Satake F, Pietro PS, Hisano H (2010) Procedimentos Básicos para Colheita de Sangue em Peixes. Circular Técnica da Empresa Brasileira de Pesquisa Agropecuária, Dourados, Mato Grosso do

Sul,Brasil.8p.https://www.infoteca.cnptia.embrapa.br/bitstream/doc/874164/1/CT201017.pdf. Acessado em 15 de Junho de 2021

32. Jonsson CM, Castro VL (2005) Bioindicadores e biomarcadores de agroquímicos no contexto da relação saúde-ambiente. Embrapa-Meio ambiente,p.5.http://www.agencia.cnptia.embrapa.br/Repositorio/Jonsson_Castro_biomarcadoresIDU4Vhi5C93K.pdf. Acessado em 30 de Maio de 2021

33. Lima MW, Santos MLS, Melo NFAC, Faial K C F, Lima MO, Nunes DM (2015) Distribuição espaçotemporal dos metais $\mathrm{Ba}, \mathrm{Na}, \mathrm{K}, \mathrm{Mn}$ e Ca nos sedimentos de fundo do estuário Furo da Laura, Amazônia Oriental, Brasil. Boletim Técnico Cientifico do CEPNOR 15(1):15-22. 10.17080/16765664/btcc.v15n1p15-22. Acessado em 30 de Maio de 2021

34. Lima DP, Santos C, Silva RS, Yoshioka ET, O, Bezerra RM (2015) Contaminação por metais pesados em peixes e água da bacia do rio Cassiporé, Estado do Amapá. Brasil 45(4):405-414. DOl:http://dx.doi.org/10.1590/1809-4392201403995

35. Lima EMM, Santos PRB, Ferreira LAR, Sousa KNS (2019) Reproductive biology of Silver Croaker (Plagioscion squamosissimus) species of fishery importance in the Lower Amazon. Pará Brazil Gaia Scientia 13(1):38-50. DOI:10.22478/ufpb.1981-1268.2019v13n1.44079

36. Lemos MAQ, Pimentel MAS (2021) Mining and environmental disasters with bauxite and kaolin waste in the municipality of Barcarena-Pará-Brasil-Amazônia. Territorium 28 (I),137-156. DOI: https://doi.org/10.14195/1647-7723_28-1_8

37. Martins LPAZ, A V, Bretano DM (2010) Avaliação da geração de Micronúcleo em juvenis de Centropomus parallellus (Robalo-Peva) expostos a diferentes concentrações salinas. In: RTC Florianópolis, SC, $2^{\circ}$ Ed pp 13-16

38. Marinho JS, Jesus IM, Asmus C I R F, Lima MO, Oliveira DC (2016) Doenças infecciosas e parasitárias por veiculação hídrica e doenças respiratórias em área industrial, Norte do Brasil. Cad Saúde Colet 24(4):443-451. DOl:https://doi.org/10.1590/1414-462x201600040120

39. Matsumoto ST et al (2006) Genotoxicity and mutagenicity of water contaminated with tannery effluents, as evaluated by the micronucleus test and comet assay using the fish Oreochromis niloticus and chromosome aberrations in onion root-tips. Genetics Molecular Biology Ribeirão Preto, (1), 148-158. https://doi.org/10.1590/S1415-47572006000100028

40. Medeiros Faial KRF, Faial K, CF Lopes I D S Lima M, O Guimarães R M Mendonça N, M (2017) Quality index of the surface water of Amazonian rivers in industrial areas in Pará, Brazil. Mar Pollut Bull 123:156-164. http://dx.doi.org/10.1016/j.marpolbul.2017.09.002 
41. Meneguetti DUO, Silva FC, Zan RA, Poletto PO, Ramos LJ (2011) Adaptação da técnica de micronúcleo em allium cepa, para futuras análises de mutagenicidade dos rios da região do Vale do Jamari, Rondônia, Amazônia Ocidental. Revista Pesquisa Criação 10(2):181-187. https://www.periodicos.unir.br/index.php/propesq/article/viewFile/423/476. Acesso 15 de Abril de 2021

42. Mesquita LCS (2020) Análise do grau de eutrofização nas águas do Furo da Laura,VIGIA-PABRASIL. Univerdiade Federal do Pará, Dissertação

43. Mersch J, Beauvais M-N, NAGEL P (1996) Induction of micronucleus in haemocytes and gill cells of zebra mussels. Dressena polymorpha, exposed to clastogens. Mutation Research, (371), p. 47-55. DOI: 10.1016 / s0165-1218 (96) 90093-2

44. Muniz DHF, Oliveira-Filho EC (2006) Metais pesados provenientes de rejeitos de mineração e seus efeitos sobre a saúde e o meio ambiente. Revista Ciências da Saúde 4(1/2):83-100. DOl:https://doi.org/10.5102/ucs.v4i1.24

45. Moller P (2005) Genotoxicity of environmental agentes assessed by the alcaline comet assay. Basic \& Clinical Pharmacology and Toxicology. (96) 3-00, 2005

46. Oliveira DC (2013) Distribuição de metais pesados e isótopos de PB em sedimentos de fundo do rio murucupi Barcarena-Pará. Dissertação, Universidade Federal do Pará

47. Oliveira-Ribeiro CA, Katsumiti A, França P, Maschio JZandoná E, Cestari MM, Vicari T, Roche H, Silva de Assis HC, Filipak Neto F (2013) Biomarkers responses in fish (Atherinella brasiliensis) of Paranaguá Bay, southern brazil, for assessment of pollutant effects. Brazilian Journal of Oceanography São Paulo 61(1):1-11. .DOl:https://doi.org/10.1590/S1679-87592013000100001

48. Oliveira HW, Valdes SAC (2019) Frequência de micronúcleos em Tilápias Oreochromis niloticus (PERCIFORMES, CICHLIDAE) de pisciculturas no município de Matutina (MG), Brazil. Revista do Comeia 1(1):1-10

49. Oliveira NCL, Teixeira HP, Lima THA, Silva JF, Oliveira NCL, Cabra I G S (2019) Análise anatomohistopatológica dos peixes expostos aos efluentes de lama vermelha lançados irregularmente na cidade de Barcarena, Pará. II Seminário de Toxicologia Veterinária

50. Oliveira DG, Paula DAJ, Murgas L D S(2020) Genotoxicidade em Danio rerio expostos a concentrações crescentes da fração solúvel do biodiesel. In: PUBVET, $4^{\circ}$ Ed. DOI: 10.31533/pubvet.v14n4a549.1-6

51. Ostling GO, Johanson KJ (1984) Microelectrophoretic study of radiation-induced DNA damages in individual mammalian cells. Biochemical and Biophisical Research Communications 1 Ed. pp.291298.DOI: https://doi.org/10.1016/0006-291X(84)90411-X

52. Pereira SFP, Lima MA, Freitas KH, Mescouto CS, Saraiva AF (2007) Estudo químico ambiental do rio Murucupi-Barcarena, PA, Brasil, área impactada pela produção de alumínio. Revista Ambi-Água 2(3):62-82. DOl:http://dx.doi.org/10.4136/ambi-agua.34

53. Piratoba ARA, Ribeiro HMC, Morales GP, Gonçalves WG (2017) Caracterização de parâmetros de qualidade da água na área portuária de Barcarena, PA. Brasil Revista Ambiente-Água 12(3):435- 
456. DOI:https://doi.org/10.4136/ambi-agua.1910

54. Porto JIR, Araujo CS, O, Feldberg E (2005) Mutagenic effects of mercury pollution as revealed by micronucleus test on three Amazonian fish species. Environ Res 97 (3), 287-292. DOI: 10.1016 / j.envres.2004.04.006

55. Ranzani-Paiva MJ et al (2013) Métodos para análise hematológica em peixes. EDUEM, Maringá, 140 p

56. Rivero CLG (2007) Frequência de micronúcleos e de danos no DNA de diferentes espécies de peixes do lago Paranoá, Brasília-DF, Brasil. 103 p. http://repositorio.unb.br/handle/10482/2626

57. Rocha CAM (2009) Avaliação da genotoxicidade do cloreto de metilmercúrio em duas espécies de Peixes neotropicais. Tese, Universidade Federal do Pará

58. Rocha CAM, Pessoa CMF, Rodrigues CAC, Pinheiro RHS, Costa ET, Guimarães AC, Burbano RR (2016) Investigation into the cytotoxity mutagenicity of the Marajó Achipelago waters using Plagioscion squamosissimus (Perciformes: Scianidae) as a biondicator. Ecotoxicol Environ Saf 132:111-115. DOI:http://dx.doi.org/10.1016/j.ecoenv.2016.05.020

59. Santos VTF, Gutierrez MP, Bay M, Bianchini-Pontuschka R, Hurtado FB (2015) Frequência de micronúcleos em tambaquis de cultivo semiintensivo em pisciculturas de Presidente Médici-RO, Porto Velho, Brasil. https://www.researchgate.net/publication/288993480

60. Santos AT, L M (2018) Análise temporal dos impactos socioambientais das barragens de rejeito na bacia hidrográfica do rio Murucupi, Barcarena - PA. Dissertação, Universidade Federal do Pará

61. Santos SL, Viana LF, Merey FM, Crispim BA, Solorzano JC, Barufatti Alexeia Cardoso CAL, LimaJunior SE (2020). Evaluation of the water quality in a conservation unit in Central-West Brazil: Metals concentrations and genotoxicity in situ. Chemosphere, (251).DOI:

ttps://doi.org/10.1016/j.chemosphere.2020.126365

62. Silva AC, Mangas AP, Palheta GDA, Melo N F A C (2011) Variação Intermareal na Composição do Ictioplâncton no Estuário do Rio Guajará-mirim (Vigia de Nazaré-Pará) em período de alta pluviosidade. Boletim Técnico Cientifico Cepnor 11(1):21-32.

DOl:http://dx.doi.org/10.32519/tjfas.v11i1.1199

63. Silva GKR (2013) Transformações socioambeintais na comunidade de Dom Manoel-Barcarena/PA. Dissertação, Universidade Federal do Prá

64. Singh NP, McCoy MT, TICE RR, Schneider EL (1988) A simple echnique for quantification of low levels of DNA damage in individual cells. Elsevier 175(1):184-191

65. Shrestha S, Kazama F (2007) Assessment of surface water quality using multivariate statistical techniques: A case study of the Fuji river basin. Japan Environmental Modelling Software 22(4):464-475. DOI:https://doi.org/10.1016/j.envsoft.2006.02.001

66. Silva Júnior AF (2013) Intoxicação crônica experimental com alumínio: padrões degenerativos, comportamentais e terapia experimental com magnésio após lesão hipocampal. Tese, Universidade Federal do Pará 
67. Silva MD, Rossi SC, Ghisi NC, Ribeiro C, A O, Cestari MM, De Assis HC S (2014) Using multibiomarker approach as a tool to improve the management plan for a Private Reserve of Natural Heritage (RPPN). Bull Environ Contam Toxicol, 92 (5) 602-608. DOI: 10.1007 / s00128-014-1230-9

68. Souto PSS (2004) Risco ecológico associado à contaminação mercurial em ecossistemas aquáticos da Amazônia: Região do Rio Tapajós, Estado do Pará, Brasil. Caracterização através de biomarcadores no gênero Cicla (Tucunarés). Acta Scientiarum Biological Sciences 35(3):395-401. DOI:https://doi.org/10.4025/actascibiolsci.v35i3.18032

69. Steinbrenner RA, Neto GG, Bragança PL, Castro EMR (2020) Mining disaster in Barcarena, Pará and media coverage: differences in duration and listening directions. Rev Eletron Comun Inf Inov Saúde 14(2):307-328. DOI:http://dx.doi.org/10.29397/reciis.v14i2.2063

70. Sultana S, Jabeen F, Sultanaa T, AL-Ghanimb KA, Al-Misnedb F, Mahbooba S (2020) Assessment of heavy metals and its impact on DNA fragmentation in different fish species. Braz J Biol 80(4):823828. DOl:https://doi.org/10.1590/1519-6984.221849

71. Thomé RG, Silva PM, Santos HB (2016) Avaliação de genotoxidade da água de um rio urbano utilizando estudo de células sanguíneas de Danio rerio. Conexão Ciência 11 (2), 9-16.DOI: https://doi.org/10.24862/cco.v11i2.415

72. Ventura AS, Corsini FE, Gabriel AMA (2015) Hematologia como biomarcador de contaminação ambiental em peixes. Nutritime Revista Eletrônica. Viçosa, $6^{\circ}$ Ed. pp, 4500-4507

73. Viana AP (2011) Ictiofauna no monitoramento da qualidade ambiental em um distrito industrial do estuário Amazônico. Belém, PA, Brasil. Dissertação, Universidade federal do Pará pp.153 p

74. Viana AP, Frédou FL, Montes CS, Rocha RM (2013) Fish histopathology and catalase activity as biomarkers of the environmental quality of the industrial district on the Amazon estuary, Brazil. Acta Scientiarum Biological Sciences 35(3):395-401. DOl:https://doi.org/10.4025/actascibiolsci.v35i3.18032

75. Wachtel CC (2017) Utilização de biomarcadores genéticos para a avaliação do principal rio de abastecimento público da cidade de Dois Vizinhos, Paraná, Brasil. Dissertação, Universidade Tecnológica Federal do Paraná $50 \mathrm{p}$

76. White PA, Rasmussen JB (1998) The genotoxic hazards of domestic wastes in surface waters. Mutat Res, (410), 223-236. DOl:https://doi.org/10.1016/S1383-5742(98)00002-7

\section{Tables}

Table 1 Parameters of total length and weight of the Plagioscion squamosissimus specimens collected in Barcarena and Vigia, in eastern Brazilian Amazonia 
Study area $\quad \mathrm{N} \quad \mathrm{TL}(\mathrm{cm})$

Weight (g)

\begin{tabular}{lccccccccc} 
& & Max & Mean & Min & SD & Max & Mean & Min & SD \\
\hline Barcarena & 16 & 35.5 & 31.91 & 28 & 2.70 & 905 & 646.19 & 239 & 195.05 \\
\cline { 2 - 10 } & 24 & 29.5 & 21.06 & 17 & 3.21 & 240 & 98.46 & 27 & 51.85 \\
\hline Vigia & 14 & 40.2 & 32.84 & 23.6 & 4.44 & 474 & 293.5 & 114 & 107.32
\end{tabular}

Table 2 Abiotic variables (Temp. = Temperature, DO = Dissolved Oxygen) recorded in the rainy and dry seasons in Barcarena and Vigia, in eastern Brazilian Amazonia.

\begin{tabular}{|c|c|c|c|c|c|c|}
\hline $\begin{array}{l}\text { Study } \\
\text { area }\end{array}$ & Season & $\begin{array}{l}\text { Temp. } \\
{ }^{\circ} \mathrm{C}\end{array}$ & $\mathrm{pH}$ & $\begin{array}{l}\text { Dissolved oxygen (mg. } \mathrm{L}^{-} \\
\text {1) }\end{array}$ & $\begin{array}{l}\text { Nitrate (mg.L' } \\
\text { 1) }\end{array}$ & $\begin{array}{l}\text { Phosphate } \\
\left(\mathrm{mg} \cdot \mathrm{L}^{-1}\right)\end{array}$ \\
\hline \multirow[t]{2}{*}{ Barcarena } & Dry & 30.36 & 6.05 & 5.60 & 2.70 & 0.078 \\
\hline & Rainy & 29.39 & 5.82 & 5.16 & 5.00 & 0.026 \\
\hline \multirow[t]{2}{*}{ Vigia } & Dry & 28.94 & 6.86 & 8.48 & 0.85 & 0.29 \\
\hline & Rainy & 29.16 & 6.37 & 7.28 & 0.49 & 0.04 \\
\hline
\end{tabular}

Source: HidroWeb-ANA (2020)

Table 3 Mean number of Plagioscion squamosissimus cells, from specimens collected in Barcarena and Vigia, which were assigned to each damage class $(0=$ no damage; $1=$ some damage; $2=$ moderate; $3=$ extensive; 4 = maximum damage) in the comet assays

\begin{tabular}{|lllllll|}
\hline Study area & \multicolumn{6}{l}{ COMET ASSAY CELL DAMAGE (mean $\pm \mathbf{s d}$ ) $\%$} \\
\cline { 2 - 7 } & $\mathbf{0}$ & $\mathbf{1}$ & $\mathbf{2}$ & $\mathbf{3}$ & $\mathbf{4}$ & Total \\
\hline Barcarena & $11.69 \pm 10.70$ & $24.13 \pm 16.34$ & $16.44 \pm 5.1$ & $20.13 \pm 13.79$ & $28.25 \pm 14.43$ & 1610 \\
\hline Vigia & $59.42 \pm 16.78$ & $22.92 \pm 8.69$ & $7.67 \pm 7.70$ & $8.5 \pm 8.28$ & $1.8 \pm 2.20$ & 1200 \\
\hline
\end{tabular}

Table 4 Frequency of nuclear abnormalities and micronuclei observed in 2000 Plagioscion squamosissimus erythrocytes from each of the specimens collected in Barcarena and Vigia in the dry and rainy seasons. $\mathrm{NC}=$ normal cells; $\mathrm{NA}=$ nuclear abnormality (evaginated cell) $; \mathrm{MN}=$ micronuclei

\begin{tabular}{|llllll|}
\hline Study area & Season & \multicolumn{4}{l|}{ MICRONUCLEUS TEST (mean \pm sd) } \\
\cline { 3 - 6 } & & NC & NA & MN & Total \\
\multirow{2}{*}{ Barcarena } & Dry & $1.93 \pm 0.25$ & $7.44 \pm 11.97$ & $4.25 \pm 6.76$ & 79,990 \\
\cline { 2 - 5 } & Rainy & $2.00 \pm 0.05$ & $3.54 \pm 4.29$ & $0.75 \pm 1.15$ & \\
Vigia & Rainy & $1.99 \pm 0.01$ & $7.21 \pm 7.67$ & $0.69 \pm 0.95$ & 28,000 \\
\hline
\end{tabular}


Table 5 Results of the one- and two-way Analyses of Variance of the variation in the length, weight, and cellular abnormalities recorded in the Plagioscion squamosissimus specimens collected from two Amazonian estuaries. $\mathrm{CA}=$ comet assay; $0-4=$ the level of genomic damage; $\mathrm{AN}=$ morphonuclear alterations; $\mathrm{MN}=$ micronuclei; $\mathrm{VIG}=$ Furo da Laura, municipality of Vigia; BAR = Murucupi River, municipality of Barcarena; $\mathrm{P}=$ probability; $\mathrm{Df}=$ degrees of freedom; $\mathrm{MS}=$ mean squares; $\mathrm{SS}=$ sum of the squares. ${ }^{*}$ significant difference

\begin{tabular}{|c|c|c|c|c|c|c|c|}
\hline Dependent variable & Factor & MS & SS & Df & Fisher's test & $\mathbf{P}$ & Pattern \\
\hline \multirow[t]{2}{*}{ Total length (cm) } & Area & 574.1 & 574.1 & \multirow[t]{12}{*}{1} & 17.69 & $<0.01^{*}$ & VIG>BAR \\
\hline & Season & 477.1 & 477.1 & & 13.91 & $<0.01^{*}$ & Dry $>$ Rainy \\
\hline \multirow[t]{2}{*}{ Weight (g) } & Area & 5998 & 5998 & & 0.085 & $>0.05$ & $\mathrm{BAR} \geq \mathrm{VIG}$ \\
\hline & Season & $2.55 \mathrm{E}+06$ & $2.55 \mathrm{E}+06$ & & 118.5 & $<0.01^{*}$ & Dry>Rainy \\
\hline CAO & \multirow[t]{8}{*}{ Area } & $1.56 \mathrm{E}+04$ & $1.56 \mathrm{E}+04$ & & 84.33 & $<0.01^{*}$ & VIG>BAR \\
\hline CA1 & & 10.01 & 10.01 & & 0.054 & $>0.05$ & $B A R \geq V I G$ \\
\hline CA2 & & 527.5 & 527.5 & & 13.08 & $<0.01^{*}$ & $\mathrm{BAR}>\mathrm{VIG}$ \\
\hline CA3 & & 926.7 & 926.7 & & 6.68 & $<0.05^{\star}$ & $\mathrm{BAR}>\mathrm{VIG}$ \\
\hline CA4 & & 4305 & 4305 & & 32.63 & $<0.01 *$ & $\mathrm{BAR}>\mathrm{VIG}$ \\
\hline NC & & 0 & 0 & & 0.094 & $>0.05$ & $B A R \geq V I G$ \\
\hline AN & & 46.36 & 46.36 & & 0.692 & $>0.05$ & VIG>BAR \\
\hline MN & & 20.85 & 20.85 & & 1.26 & $>0.05$ & $\mathrm{BAR}>\mathrm{VIG}$ \\
\hline
\end{tabular}

Table 6 Results of the Redundancy Analysis (RDA) of the effects of the different variables (Fig. 3) on the Plagioscion squamosissimus specimens collected during the present study from two estuaries in the Brazilian Amazon basin

\begin{tabular}{|lll|}
\hline Parameter & Axis 1 & Axis 2 \\
\hline Eigenvalue & 0.7631 & 0.0810 \\
\hline Variation explained (cumulative) & 76.31 & 84.41 \\
\hline Pseudo-canonical correlation & 0.9941 & 0 \\
\hline Adjustment explained (cumulative) & 100 & - \\
\hline
\end{tabular}

\section{Figures}



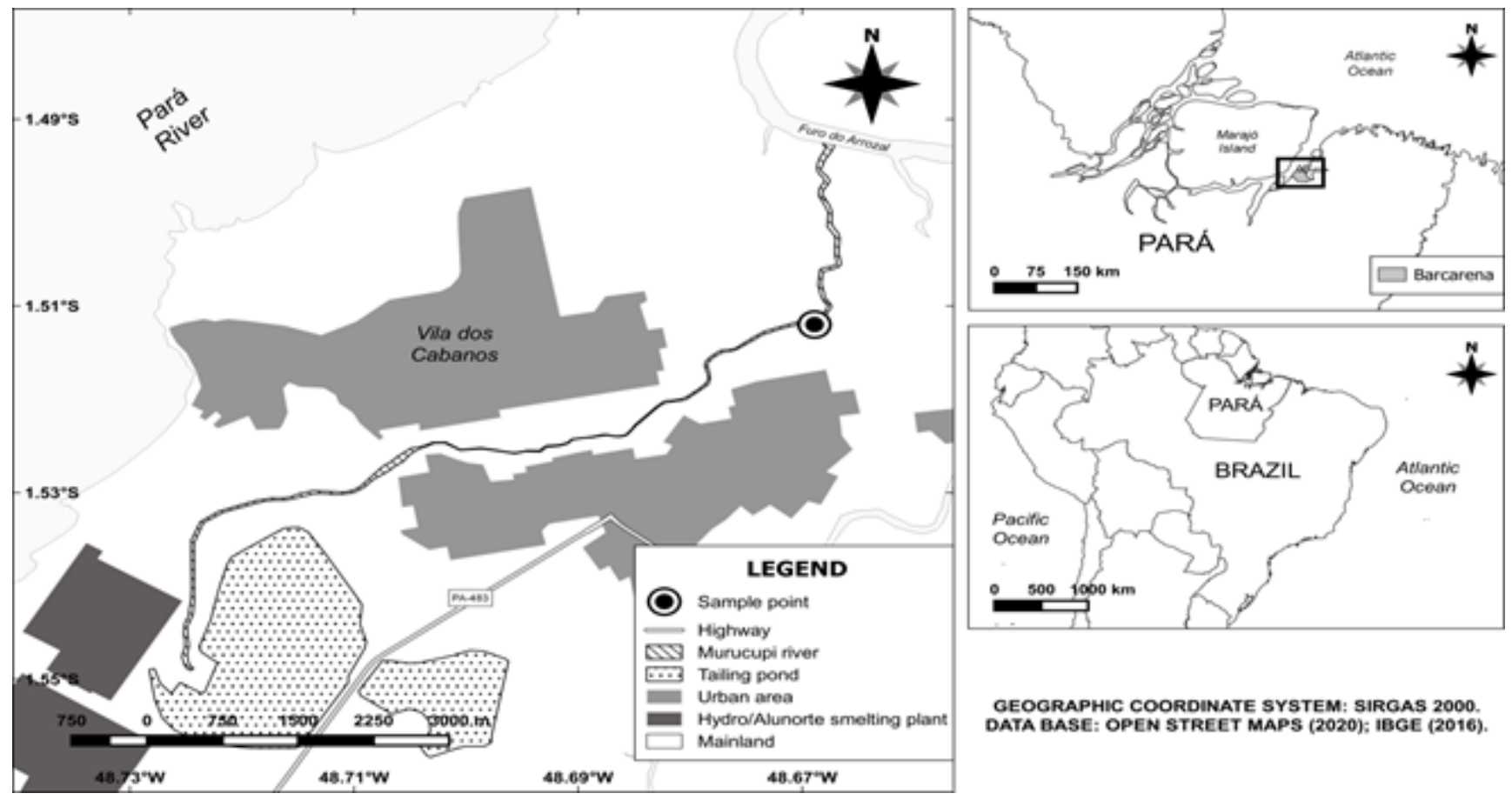

GEOGRAPHIC COORDINATE SYSTEM: SIRGAS 2000 DATA BASE: OPEN STREET MAPS (2020): IBGE (2016).

Figure 1

Location of the sampling point on the Murucupi River in Barcarena, Pará state, Brazil, where the P. squamosissimus specimens were collected in August 2020 and March 2021

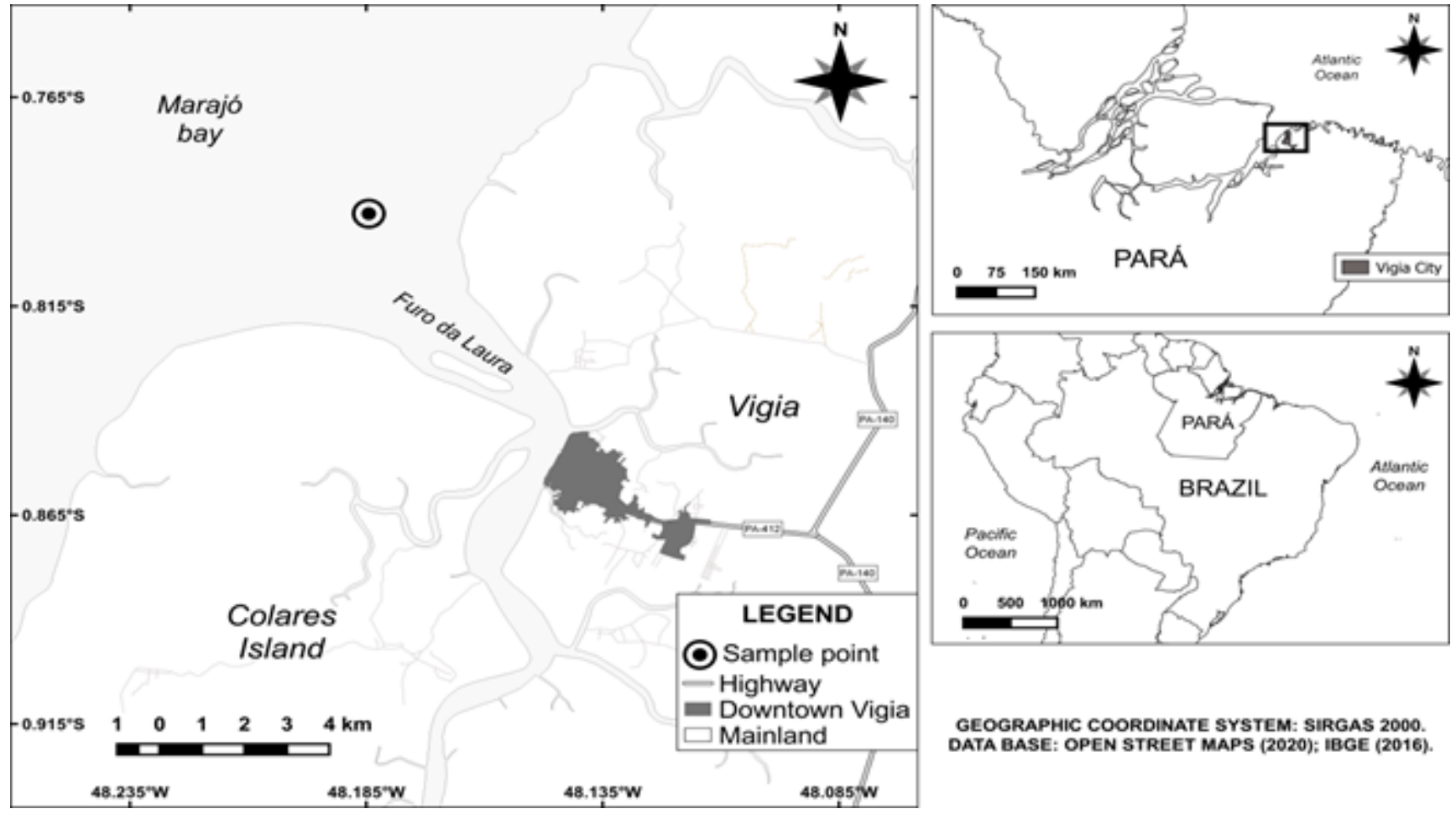

Figure 2

Location of the sampling point off the Furo da Laura estuary in Vigia, Pará state, Brazil, where the P. squamosissimus specimens were collected in March 2021 


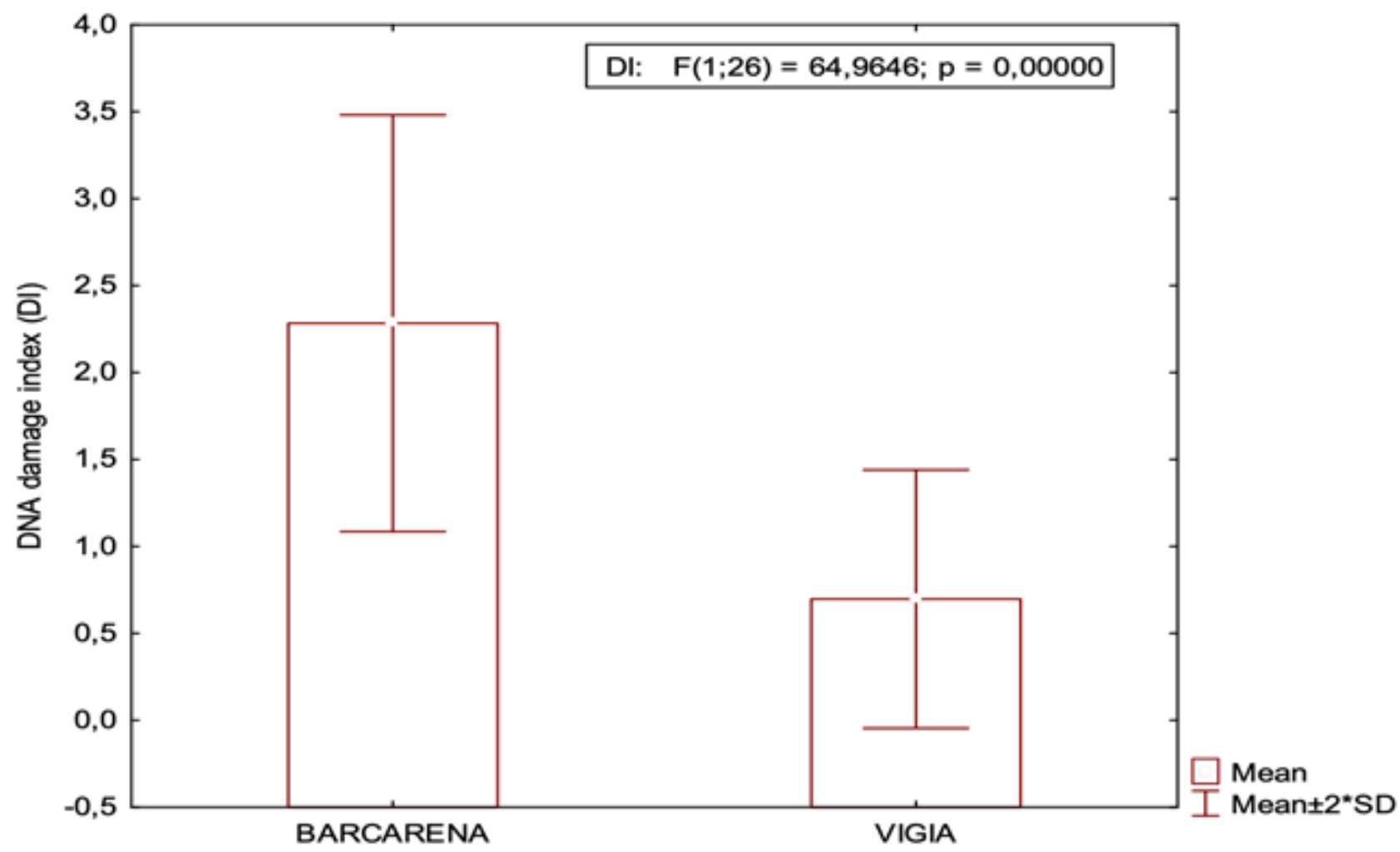

Figure 3

Comet assay in Plagioscion squamosissimus. Comparison of DNA damage index between group Infected (Barcarena) and the control group (Vigia) 


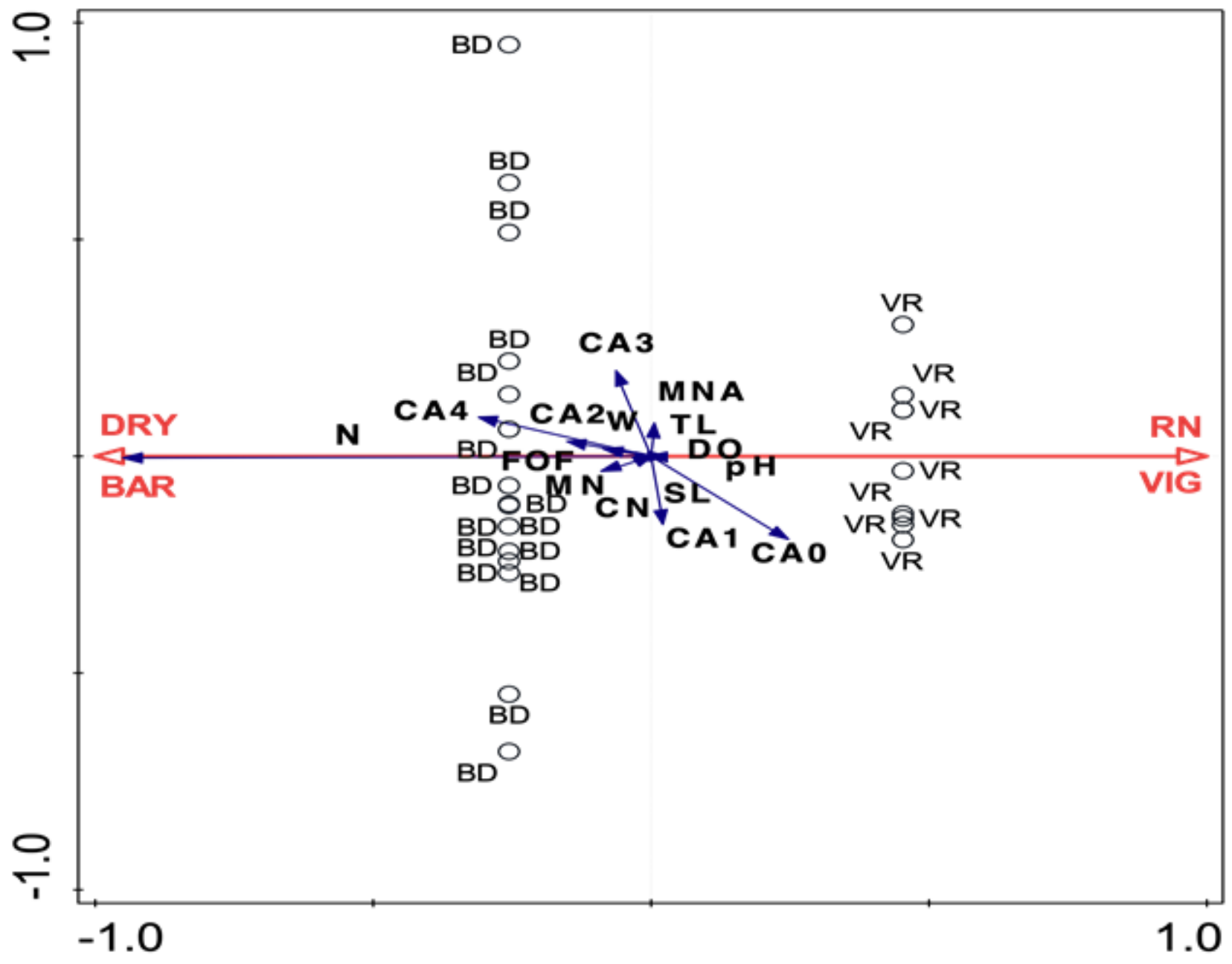

Figure 4

Ordination diagram of the first two axes of the Redundancy Analysis of the level of damage recorded in the comet assay $(\mathrm{CO}-\mathrm{C} 4)$, body weight $(\mathrm{g})$, total length $(\mathrm{cm})$, morphological nuclear alterations $(\mathrm{MNA})$, cells with micronuclei $(\mathrm{MN})$, and normal cells $(\mathrm{CN})$ in the Plagioscion squamosissimus specimens collected from two estuaries in eastern Brazilian Amazonia. $\mathrm{RN}=$ rainy season; $\mathrm{VR}=$ Vigia Rainy; $\mathrm{BD}=$ Barcarena Dry

\section{Supplementary Files}

This is a list of supplementary files associated with this preprint. Click to download.

- Supplementary.docx 